\title{
Revitalisasi Peran Srategis Sekretaris Daerah Dalam Mengakselerasi Reformasi Birokrasi
}

\author{
Ilyas \\ STISIP Veteran Palopo \\ Koresponden, Email: ilyas.ilyas@gmail.com
}

\begin{abstract}
ABSTRAK
Penelitian ini mengkaji revitalisasi peran strategis Sekretaris Daerah dalam akselerasi reformasi birokrasi, dengan metode penelitian deskriptif kualitatif, dan desain penelitian evaluatif, analitik, eksploratif, eksplanatif dan komparative, serta teknik analisis kualitatif. Hasilnya, secara umum dan keseluruhan, ada 8 (delapan) dimensi pokok dan utama satu kesatuan kelompok peran strategis seorang Sekretaris Daerah dalam birokrasi pemerintahan yaitu: (1) Pemimpin (Leader) birokrasi dan ASN. (2) Manajer (Manager) birokrasi dan ASN, (3) Konseptor, konsultan, desainer, formulator kebijakan daerah, organisasi birokrasi dan ASN, (4) Administrator birokrasi, ASN dan pelayanan public, (5) Koordinator, komunikator, fasilitator, mediator, motivator, dinamisator, energisator organisasi birokrasi, ASN dan pelayanan public, (6) Supervisor, educator, trainer, learner, advocator, promotor dan empower organisasi birokrasi, ASN dan pelayanan public, (7) Implementor dan eksekutor kebijakan organisasi birokrasi, ASN dan pelayanan public, (8) Controller, monitor dan evaluator organisasi birokrasi, ASN dan pelayanan publik. Model revitalisasi peran strategis Sekretaris Daerah dalam akselerasi reformasi birokrasi adalah revitalisasi peran Sekda sebagai aktor Reinventer Government, Leader Manager birokrasi, Entrepreuner birokrasi, aktor New Public Management (NPM), a ktor Strategi Banishing Bureucracy reformasi birokrasi, dan aktor reformasi birokrasi berbasis kearifan budaya lokal. Disarankan untuk mempertimbangkan penerapan model revitalisasi peran strategis Sekretaris Daerah dalam akselerasi reformasi birokrasi tersebut.
\end{abstract}

Kata Kunci: Revitalisasi, peran strategis, tantangan peran, reformasi birokrasi, Sekretaris Daerah

\begin{abstract}
This research explore revitalization a strategic role of Local Secretary owned Local Government to accelerate bureaucracy reformation, by use a qualitative descriptive as method, and an evaluative, analytic, explorative, explanative and comparative as investigation design, and a qualitative as analyses. Results, by all dan generally, there are eight main dimensions as unity at strategic role played by Local Government Secretary within government bureaucracy include: (1) Leader, (2) Manager, (3) Conseptor, consultant, designer and formulator for local policy and officer or employment, (4) Administrator for public service and employment, (5) Coordinator, communikator, facilitator, mediator, motivator, dynamisator, energizer, (6) Supervisor, educator, trainer, learner, advocator, promotor and empower for bureaucracy, public service and employment, (7) Implementor and executor, (8) Controller, monitor and evaluator. Revitalization model of strategic role of Local Government Secretrary to accelerate bureaucracy reformation are revitalization as Reinventer Government actor, Leader Manager, Entrepreuner, New Public Management (NPM) actor, Banishing Bureucracy Strategy actor, and actor bureaucracy reformation based local wisdom. Recommended to actualize those revitalization model as mentioned above in order to accelerate any strategic role of Local Government Secretary into bureaucracy reformation it.
\end{abstract}

Keywords: Law Enforcement; Restorative Justice; Criminal act 


\section{PENDAHULUAN}

Pemerintahan Negara bangsa merupakan organisasi skala besar yang menjadi wahana pemersatu dan inter-konektivitas hubungan Negara, Pemerintah dan Rakyat (NPR) dalam tri-penyelenggaraan yakni urusan pemerintahan, pembangunan multisektoral dan pelayanan publik (public service) multidimensional (Seetjipto, 2019). Dalam inter-konektivitas tersebut, Pemerintah berada di tengah yang memiliki posisi urgen, sentral, vital dan strategis dalam menjalankan prinsip-prinsip atau fungsi-fungsi manajemen (planning, organizing, actualize, controlling, evaluation/ POACE) tri-penyelenggaraan tersebut (Hendrajit, 2017). Dalam perspektif sistem ketatanegaraan modern di Indonesia, Pemerintah secara institusional atau kelembagaan mengacu kepada konsep trias-politica yakni mencakup tri-lembaga besar dan vital yakni lembaga legislatif, lembaga eksekutif dan lembaga yudikatif (Kusmanto, 2014). Sedangkan dalam perspektif tatanan pemerintahan yang lebih spesifik, umumnya pembicaraan tentang Pemerintah (Government) mengarah atau ditujukan kepada Lembaga Eksekutif, yang bentuk organisasi atau kelembagaannya berhirarki atau berjenjang serta diklasifikasi ke dalam dua level tingkatan besar yakni Pemerintah Pusat (Central Government) yang dikepalai/dipimpin/dinahkodai oleh Presiden-Wakil Presiden yang dibantu oleh Sekretaris Kabinet beserta sejumlah awak yang disebut menteri, dan Pemerintah Daerah (Local Government) yang dikepalai/dipimpin/dinahkodai oleh Kepala Daerah (GubernurWakil gubernur untuk Provinsi, Bupati-Wakil bupati untuk Kabupaten, Waikota-Wakil waikota untuk Kota) yang dibantu Sekretaris Daerah, asisten dan sejumlah kepala instansi (kantor, dinas, badan). Kedua level organisasi pemerintah tersebut secara umum dan keseluruhan disebut Pemerintahan Nasional (Sosiawan 2015).

Khusus di level organisasi pemerintahan daerah, salah satu komponen lembaga yang bersifat sentral dan strategis di dalamnya adalah Sekretariat Daerah (Setda). Peraturan Pemerintah (PP) Nomor 41 Tahun 2007 Tentang Perangkat Daerah khususnya BAB IV Pasal 10 ayat (1) memposisikan Sekertariat Daerah sebagai unsur staf. Demikian pula Undang-Undang Pemerintahan Daerah No.23 Tahun 2014 (UU Pemda) memposisikannya sebagai Perangkat Daerah bersama dengan Sekretariat DPRD, Inspektorat, dinas, badan (ayat (1), (2) Pasal 209). Sebagai perangkat daerah, Sekretariat Daerah bertugas melaksanakan urusan pemerintahan yang menjadi kewenangan Daerah serta melaksanakan tugas pembantuan (ayat (3) Pasal 209), bertugas dan berkewajiban membantu Kepala Daerah (Gubernur, Bupati, Walikota) dalam penyusunan kebijakan dan pengoordinasian administratif terhadap pelaksanaan tugas Perangkat Daerah (dinas daerah dan lembaga teknis daerah) serta pelayanan administratif, dan sekaligus bertanggung jawab kepada kepala daerah (ayat (2) (3) Pasal 213 UU Pemda, Pasal 10 ayat (2) PP Perangkat Daerah). Sedangkan fungsi dari Sekertariat Daerah adalah a. penyusunan kebijakan pemerintah daerah, b. pengoordinasian pelaksanaan tugas dinas daerah dan lembaga teknis daerah, c. pemantauan dan evaluasi pelaksanaan kebijakan pemerintah daerah, d. pembinaan administrasi dan aparatur pemerintah daerah; dan e. pelaksanaan tugas lain yang diberikan oleh bupati/walikota sesuai dengan tugas dan fungsinya (Pasal 10 ayat (3) PP Perangkat Daerah). 
Sekretariat Daerah dipimpin oleh Sekretaris Daerah (ayat (1) Pasal 213 UU Pemda). Dengan demikian, Sekretariat Daerah yang dipimpin dan dikelola oleh seorang aktor birokrat bernama Sekretaris Daerah (SEKDA) dengan sebutan seperti: Sekretaris Daerah Provinsi (disebut Sekprov.) untuk Pemerintahan Provinsi, Sekretaris Daerah Kabupaten (disebut Sekkab.) untuk Pemerintahan Kabupaten, dan Sekretaris Daerah Kota (disebut Sekkot.) untuk Pemerintahan Kota. Secara umum, Sekretaris Daerah (SEKDA) mempunyai tugas, kewajiban, fungsi dan kewenangan secara kelembagaan yang ada atau melekat pada Sekretariat Daerah (Setda). Dengan demikian, SEKDA mempunyai peran strategis dalarn menjalankan roda aparatur sipil negara pada pemerintahan daerah provinsi dan kabupaten atau kota, disamping sebagai karier tertinggi dalam jabatan puncak eksekutif (top executive) pada pemerintahan daerah. Tugas dan fungsi Sekda disamping sebagai unsur staf pelaksana yang membantu dan bertanggungjawab langsung kepada Gubemur atau Walikota/Bupati, juga sebagai manajer dalam mengelola setiap kebijakan daerahnya. (Hamirul, Masnun \& Elsyra, 2018).

Tugas dan fungsi yang demikian semakin menuntut seorang SEKDA untuk memiliki kemampuan dan kompetensi maksimal dalam menjalankan tugas dan fungsinya sebagai aparatur untuk memberikan pelayan terbaik bagi publik dalam wilayahnya, mengkoordinir setiap satuan kerja perangkat daerah (SKPD)-nya, menjaga kewibawaan dan melaksanakan setiap instruksi atasanya (kepala pemerintahan), mengatur hubungan baik dan kerjasaman dengan pemangku kepentingan (stakeholder) khususnya DPRD maupun elemen-elemen elit lainya (Destianingrum, Hananto, \& Sa'adah, 2017). Kemampuan dan kompetensi tersebut akan tercermin dari kinerjanya dalam membangun daerahnya, baik menyangkut kemakmuran dan kesejahteraan daerahnya maupun kemampuan aparatur dalam memberikan pelayanan terbaik kepada publiknya di era otonomi daerah (otda) dan transisi demokrasi sekarang ini dan ke depan.

Seiring dinamika pembentukan daerah baru (provinsi, kabupaten, kota) sejak berlakunya UU Otonomi Daerah dan UU Pemerintahan Daerah (perubahan UU No. 22 Tahun 1999 kepada UU No. 32 Tahun 2004, UU No. 12 Tahun 2008 dan UU No.23 Tahun 2014) sampai sekarang, di seluruh Indonesia (sesuai dengan jumlah daerah provinsi, kabupaten dan kota yang ada) tercatat sebanyak 524 orang Sekda, terdiri atas 34 orang Sekprov., 398 orang Sekkab., dan 93 orang Sekkot (Hamidi, 2011). Hal ini menunjukkan betapa besar dan banyaknya aktor Sekda yang memainkan fungsi dan peran sebagai top executive and top manager birokrasi pada berbagai organisasi pemerintahan daerah. Keberadaan seluruh Sekretaris Daerah itulah yang sebenarnya menentukan sifat, bentuk, warna, corak dan cita rasa serta kualitas birokrasi publik di setiap pemerintahan daerah (Thoha, 2007). Bukan Kepala Daerah melainkan Sekretaris Daerah-lah yang sesungguhnya menjadi kunci keberhasilan dan kegagalan setiap dan seluruh organisasi birokrasi pemerintahan lokal dan nasional dalam mewujudkan model birokrasi yang ideal. Sekretaris Daerah-lah yang dapat berperan penting sebagai dokter birokrasi dalam mendiagnosis, mengobati dan menyembuhkan birokrasi yang sakit dari virus penyakit yang bernama patologi birokrasi akibat politisasi birokrasi yang terlalu berlarut- 
larut. Oleh karena itu, jika Sekretaris Daerah-nya kurang sehat, sakit atau juga menderita penyakit patologi akut-kronis maka secara langsung dan tidak langsung birokrasi pun akan menderita sakit parah yang akan sulit disembuhkan, bahkan jika pun diobati kemungkinannya akan mengalami multi drug resistance (MDR). Situasi dan kondisi birokrasi yang sakit dan patologi politik itulah yang kemudian mendorong munculnya salah satu tawaran inovasi baru berupa jenis obat detoxic bernama "reformasi birokrasi" sebagai model atau metode pendekatan baru untuk mengeluarkan birokrasi dari keterpurukan kinerja akibat pandemi virus penyakit morale hazard yang sudah lama bersarang dalam perilaku dan mental oknum politikus, birokrat dan aparatur birokrasi itu sendiri.

Gagasan konseptual dan praktek "reformasi birokrasi” muncul sebagai pilihan alternatif universal pada berbagai pemerintahan negara di dunia terutama di Negara-negara maju yang kemudian diglobalisasikan kepada Negara-negara berkembang termasuk di Indonesia. Tuntutan untuk mengadopsi penerapan konsep dan praktek reformasi birokrasi di Indonesia mulai bergema/ bergaung deras sejak digantinya rezim orde baru menjadi era reformasi Tahun 1998/1999 dengan dibukanya kran demokrasi, era desentralisasi dan otonomi daerah hingga era transisi demokrasi sekarang ini. Selama interval waktu 21 tahun (1999-2020), berbagai agenda kebijakan politik dan hukum serta program-program reformasi birokasi telah dibuat dan diluncurkan oleh Pemerintah (Sitindjak, 2010). Khusus mengenai kebijakan hukum, kronologi peraturan perundang-undangan yang pernah dan masih berlaku dimulai dari PERMENPAR Nomor PER/15/M.PAN/7/20o8 Tentang Pedoman Umum Reformasi, Peraturan Presiden (PERPRES) Nomor 81 Tahun 2010 Tentang Grand Design Reformasi Birokrasi, Peraturan Menteri Pemberdayaan Aparatur Negara (PERMENPAN) No.PER/15/M. PAN/7/2009 Tentang Pedoman Umum Reformasi Birokrasi, PERMEN PAN RB No. 20 Tahun 2010 Tentang Road Map Reformasi Birokrasi 2010-2014, Keputusan KMA No.43/KMA/SK/III/2013 Tentang Penunjukan Koordinator Assesor Penilaian Mandiri Pelaksanaan Reformasi Birokrasi, PERPRES No. 81 Tahun 2011 Tentang Grand Design Reformasi Birokrasi 2010-2025, Permen PAN RB No. 7 dan 8 Tahun 2011 Pedoman Pengajuan dan Penilaian Dokumen Usulan Reformasi Birokrasi K/L, Permen PAN RB No. 9 Tahun 2011 Tentang Pedoman Penyusunan Road Map Reformasi Birokrasi K/L dan Pemerintah Daerah, Permen PAN RB No. 10 Tahun 2011 Tentang Pedoman Pelaksanaan Program Manajemen Perubahan, Permen PAN RB No. 11 Tahun 2011 Tentang Kriteria dan Ukuran Keberhasilan Reformasi Birokrasi, Permen PAN RB No. 12 Tahun 2011 Tentang Pedoman Penataan Tatalaksana (Business Process), Permen PAN RB No. 13 Tahun 2011 Tentang Pedoman Pelaksanaan Quick Wins, Permen PAN RB No. 14 Tahun 2011 Tentang Pedoman Pelaksanaan Program Manajemen Pengetahuan (Knowledge Management), Permen PAN RB No. 15 Tahun 2011 Tentang Mekanisme Persetujuan Pelaksanaan Reformasi Birokrasi dan Tunjangan Kinerja Bagi K/L, Permen PANRB No.11 Tahun 2015 Tentang Road Map Reformasi Birokrasi 2015-2019.

Mengacu kepada Manajemen Pelaksanaan Reformasi Birokrasi yang tertuang dalam Bab VII Road Map Reformasi Birokrasi 2015-2019 Kemen PAN \& RB (2015) bahwa organisasi 
pelaksanaan reformasi birokrasi terdiri dari 2 (dua) tingkatan, yaitu Tim Pengarah dan Tim Pelaksana, yang masing-masing mempunyai tugas dan peran. Pertama, Tim Pengarah Reformasi Birokrasi Instansi Pusat dan Pemerintah Daerah dipimpin langsung oleh Menteri/Kepala Lembaga/Gubernur/Bupati/Walikota. Sekretaris Tim dipegang oleh Sekretaris Jenderal/Sekretaris Utama/ Sekretaris Daerah. Kedua, Tim Pelaksana Reformasi Birokrasi dipimpin oleh Sekretaris Jenderal/ Sekretaris Utama/Sekretaris Daerah. Sekretaris dipegang oleh salah satu pejabat eselon II. Hal ini berarti bahwa SEKDA (Sekprov., Sekkab., Sekkot.,) merupakan Sekretaris Tim reformasi birokrasi pada pemerintah daerah (provinsi, kabupaten, kota), dan sekaligus sebagai Pemimpin (Leader) tim pelaksana reformasi birokrasi di daerahnya. Dengan demikian, SEKDA memainkan peran strategis dalam akselerasi reformasi birokrasi di lembaga birokrasi publik pemerintahan daerahnya. Hal ini juga berarti bahwa kondisi pelaksanaan reformasi birokrasi yang jalan di tempat dan tanpa perubahan signifikan terutama dalam satu dekade terakhir (2010 - 2019) adalah karena peran SEKDA belum optimal/ efektif serta masih bermasalah, sehingga perlu dievaluasi, dikaji dan dianalisis. Atas dasar itu maka permasalahan pokok kajian ini adalah bagaimanakah sesungguhnya peran Sekretaris Daerah, tantangan permasalahan yang dihadapi, serta bagaimana model revitalisasi peran strategis Sekretaris Daerah dalam mengakselerasi reformasi birokrasi di lingkup pemerintahan daerahnya.

\section{METODE PENELITIAN}

Tipe penelitian adalah deskriptif kualitatif yakni menggunakan dasar-dasar teori-teori dan kebijakan hukum yang ada untuk memecahkan permasalahan penelitian (Bodgan \& Taylor, 2009). Desain penelitian evaluatif, analitik, eksploratif, eksplanatif dan studi komparatif (Creswell, 2010, 2015). Lokasi penelitian Luwu Raya, yang mencakup empat daerah kabupaten/ kota otonom (Kota Palopo, Kabupaten Luwu, Kabupaten Luwu Timur, Kabupaten Luwu. Utara), yang masing-masing satuan pemerintahan daerah otonom tersebut memiliki Sekretaris Daerah. Sumber data adalah data sekunder dan data primer. Data dikoleksi melalui dua pendekatan yakni library study (studi kepustakaan dan dokumentasi) dan field study (studi lapangan: survei, observasi, wawancara). Instrumen penelitian penulis sendiri dengan dibantu oleh beberapa tenaga pendamping, pedoman observasi atau survei, pedoman wawancara, dan perlengkapan peralatan lainnya. Data diolah, dianalisis dan dikonstruksikan secara menyeluruh, sistematis dengan menjelaskan hubungan antara berbagai jenis data. Data dianalisis secara kualitatif dengan menggunakan prosedur penelitian kualitatif yakni editing, klasifikasi, interpretasi, reduksi, pengabsahan dan penarikan kesimpulan dengan cara deduktif-induktif (Miles \& Huberman, 2012; Moleong, 2014).

\section{PEMBAHASAN}

\section{A. Peran Multidimensional Sekretaris Daerah dalam Birokrasi Publik Pemerintahan Daerah}

Negara dan Pemerintah melalui kebijakan hukum peraturan perundang-undangan pada dasarnya telah menetapkan kedudukan dan status, tugas, fungsi dan kewenangan Sekretaris Daerah (Sekda) seperti tertera pada Matriks 1. 
Matriks 1 Deskripsi Umum kedudukan dan status, tugas, fungsi dan kewenangan Sekretariat Daerah

\begin{tabular}{|c|c|c|c|}
\hline No. & $\begin{array}{l}\text { Determinan } \\
\text { Sekda }\end{array}$ & Uraian & Sumber Kebijakan \\
\hline \multirow[t]{3}{*}{1} & $\begin{array}{l}\text { Kedudukan } \\
\text { dan status }\end{array}$ & $\begin{array}{l}\text { Sebagai pimpinan/ pemimpin Sekretariat } \\
\text { Daerah }\end{array}$ & $\begin{array}{l}\text { Ayat (4) Pasal 10 PP No. 41/ } 2007 \\
\text { Ayat (1) Pasal } 213 \text { UU No.23/2014 }\end{array}$ \\
\hline & & $\begin{array}{l}\text { Berkedudukan dibawah dan bertanggung jawab } \\
\text { kepada Kepala Daerah (Gubernur, Bupati, } \\
\text { Walikota) }\end{array}$ & $\begin{array}{l}\text { Ayat (5) Pasal 10 PP No. 41/ } 2007 \\
\text { Ayat (3) Pasal } 213 \text { UU No.23/2014 }\end{array}$ \\
\hline & & $\begin{array}{l}\text { - Pejabat Pimpinan Tinggi ASN } \\
\text { - Pejabat Administrasi ASN } \\
\text { - Pejabat Fungsional ASN } \\
\text { - Pejabat yang Berwenang } \\
\text { - Pejabat Pembina Kepegawaian }\end{array}$ & $\begin{array}{l}\text { Angka 8,10, 12, 13, } 14 \text { Pasal } 1 \text { UU } \\
\text { ASN No.5/2014 }\end{array}$ \\
\hline 2 & $\begin{array}{l}\text { Tugas dan } \\
\text { kewajiban }\end{array}$ & $\begin{array}{l}\text { Membantu Kepala Daerah dalam penyusunan } \\
\text { kebijakan dan pengoordinasian administratif } \\
\text { terhadap pelaksanaan tugas Perangkat Daerah } \\
\text { (dinas daerah dan lembaga teknis daerah) serta } \\
\text { pelayanan administratif. }\end{array}$ & $\begin{array}{l}\text { Ayat (2) Pasal } 213 \text { UU No.23/2014 } \\
\text { Ayat (2) Pasal 10 PP No. 41/ } 2007\end{array}$ \\
\hline 3 & Fungsi & $\begin{array}{l}\text { a. Menyusun kebijakan pemerintah daerah } \\
\text { b. Mengoordinasikan pelaksanaan tugas dinas } \\
\text { daerah dan lembaga teknis daerah } \\
\text { c. Memantau dan mengeva!uasi pelaksanaan } \\
\text { kebijakan pemerintah daerah } \\
\text { d. Pembinaan administrasi dan aparatur } \\
\text { pemerintah daerah } \\
\text { e. Melaksanakan tugas lain yang diberikan oleh } \\
\text { Kepala Daerah (Gubernur, Bupati, Walikota) } \\
\text { sesuai dengan tugas dan fungsinya }\end{array}$ & Ayat (3) Pasal 10 PP No. 41/ 2007 \\
\hline 4 & Kewenangan & $\begin{array}{l}\text { - Melaksanakan proses pengangkatan, } \\
\text { pemindahan, dan pemberhentian Pegawai } \\
\text { ASN sesuai dengan ketentuan peraturan } \\
\text { perundang-undangan } \\
\text { - Menetapkan pengangkatan, pemindahan dan } \\
\text { pemberhentian pegawai ASN dan pembinaan } \\
\text { manajemen ASN di instansi pemerintah sesuai } \\
\text { dengan ketentuan peraturan perundang- } \\
\text { undangan. }\end{array}$ & $\begin{array}{l}\text { Angka 13, } 14 \text { Pasal 1 UU ASN } \\
\text { No.5/2014 }\end{array}$ \\
\hline
\end{tabular}

Berdasarkan Matriks 1 tersebut maka dapat dipetakan sejumlah peran strategis Sekretaris Daerah (SEKDA), antara lain: Pertama, Pemimpin (Leader) dan/ atau pimpinan organisasi birokrasi dan ASN (Pasal 1o PP No. 41 Tahun 2007, Pasal 213 UU No.23 Tahun 2014, Pasal 1 UU No.5 Tahun 2014) yaitu: SEKDA berperan sebagai pemimpin bagi keseluruhan organisasi birokrasi pemerintahan daerah terutama dan khususnya Sekretariat Daerah (Setda) yang merupakan salah satu perangkat daerah (provinsi, kabupaten, kota) (ayat (1) (2) Pasal 209 UU No.23 Tahun 2014 jo UU No.9 Tahun 2015, disebut UU Pemda). Sebagai Perangkat Daerah, Sekretariat Daerah bertugas melaksanakan urusan pemerintahan yang menjadi kewenangan Daerah dan juga tugas pembantuan (ayat (3) UU Pemda), dan pelaksanaan tugas tersebut bersifat koordinatif dan fungsional (ayat (4) UU Pemda). Mengacu kepada Pasal 208 ayat (2) bahwa perangkat daerah diisi oleh pegawai aparatur sipil Negara (ASN), berarti SEKDA berperan memimpin semua organisasi unit kerja instansi (dinas-dinas, kantor-kantor, badan-badan, UPTD) yang ada di dalam lingkup organisasi perangkat daerah/ OPD serta menjadi pimpinan bagi seluruh ASN dan para kepala instansi. Dengan demikian 
dapat dikatakan bahwa SEKDA berperan vital dan strategis sebagai top leader executive, top leader organisasi birokrasi publik di pemerintahan daerah (provinsi, kabupaten, kota), sehingga harus memiliki kemampuan dan kompetensi leadership yang baik, unggul dan efektif serta professional karena memimpin organisasi profesi. Kedua, Manajer (Manager) organisasi birokrasi dan ASN (Pasal 10 PP No. 41 Tahun 2007, Pasal 213 UU No.23 Tahun 2014, Pasal 1 UU No.5 Tahun 2014), yaitu: SEKDA berperan sebagai manajer bagi organisasi/ lembaga Sekretariat Daerah dan OPD ((dinas-dinas, kantor-kantor, badan-badan, UPTD) dan manajer bagi seluruh ASN daerah. Oleh karena itu, SEKDA harus memiliki aneka ragam jenis kompetensi yang diperlukan seperti manajemen organisasi, manajemen administrasi, manajemen personalia, manajemen SDM ASN, manajemen keuangan, manajemen kinerja, manajemen pelayanan publik, manajemen pembangunan daerah lintas sektoral, manajemen pemerintahan, manajemen konflik, manajemen lingkungan kerja, dan lainnya. Untuk tujuan itu maka sudah seharusnya seorang SEKDA memiliki kemauan dan motivasi belajar yang tinggi baik secara formal maupun non-formal, proaktif mempelajari praktek-praktek manajemen yang baik dan bermanfaat pada daerah-daerah lain yang sudah berpengalaman dan berprestasi baik di Indonesia maupun di Negara-negara lain bahkan jika memungkinkan untuk melakukan studi banding (benchmarking) untuk memperoleh pengetahuan dan wawasan yang lebih luas serta pengalaman-pengalaman baru (Moonto, et.al, 2018). Intinya bahwa SEKDA harus bersedia menempuh berbagai cara untuk belajar konsep, teori dan praktek manajemen professional untuk diterapkan di daerahnya. Dengan demikian, SEKDA berperan sentral dan strategis sebagai leader-manager organisasi birokrasi pemerintahan daerah.

Ketiga, Konseptor, konsultan, desainer, formulator kebijakan daerah, organisasi birokrasi dan ASN (Pasal 10 PP No. 41 Tahun 2007, Pasal 213 UU No.23 Tahun 2014, yaitu: SEKDA berperan sebagai pemikir, penggagas ide pemikiran, penyusun/ perancang konsep serta perumusan agenda politik dan formula kebijakan baik kebijakan penyelenggaraan pemerintahan daerah, kebijakan pembangunan daerah terlebih kebijakan pelayanan publik. Umumnya pada saat kampanye politik dan pemilukada serentak, Kepala Daerah yang terpilih menebar aneka janji-janji politik kepada masyarakat, membuat kontrak politik dan sosial dengan komponen masyarakat tertentu. Oleh karena itu, SEKDA berperan penting untuk menjabarkan janji-janji politik tersebut ke dalam agenda politik dan formulasi kebijakanprogram pembangunan sektoral dan pelayanan publik. SEKDA harus mampu menggagas pemikiran inovatif, merancang dan merumuskan suatu model kebijakan dan program yang sesuai dengan kebutuhan masyarakat dan keunggulan daerah sehingga akan terjadi perubahan-perubahan yang signifikan dalam strategi pengelolaan birokrasi dan pelayanan public yang lebih baik berdasarkan prinsip-prinsip efisiensi dan efektivitas, transparansi, akuntabilitas, responsibilitas, responsivitas, dan professionalisme.Demikian pula aneka pembangunan infrastruktur, sarana prasarana, fasilitas umum dan sosial ekonomi akan semakin terarah, tepat guna dan sasaran dalam memenuhi kebutuhan dan kepentingan masyarakat dan daerah. Keempat, Administrator birokrasi, ASN dan pelayanan publik (UU Pemda, UU ASN, UU Perangkat Daerah), yaitu: SEKDA berperan sebagai perancang metode pendekatan atau model pelayanan administrasi yang inovatif dan unggul baik administrasi organisasi birokrasi umum dan khusus, administrasi perkantoran, administrasi tata usaha, administrasi kinerja ASN, administrasi keuangan dan pembangunan daerah, terlebih administrasi pelayanan publik pada berbagai sector dan perizinan investasi. SEKDA memiliki tanggungjawab yang besar untuk menciptakan, membangun, mengelola dan mengembangkan sistem administrasi organisasi birokrasi public dalam segala aspek baik 
teknis operasional maupun manajerial sebab sistem administrasi tersebut sangat berguna dan berperan penting dalam mengatasi patologi birokrasi dan mewujudkan model birokrasi yang ideal di lingkungan pemerintahan daerahnya. Khusus dalam konteks administrasi pelayanan publik, SEKDA perlu memiliki filosofi, paradigma, pengetahuan, pemahaman, konsep, dan metode analisis dan praktek administrasi yang baik untuk memanage berbagai sector (sosial budaya, hukum, politik, pendidikan, kesehatan, ketenagakerjaan, permukiman dan perumahan, ekonomi, industri dan perdagangan, perhubungan dan transportasi, telekomunikasi dan informasi, pertanian, perkebunan, peternakan, kehutanan, kelautan dan perikanan, kepariwisataaan, keolahragaan, pertahanan keamanan, dan lainnya) sehingga pengelolaan birokrasi benar-benar sesuai kebutuhan dan harapan masyarakat dan daerah.

Kelima, Koordinator, komunikator, fasilitator, mediator, motivator, dinamisator, energisator organisasi birokrasi, ASN dan pelayanan publik (UU Pemda, UU ASN, UU Perangkat Daerah), yaitu: SEKDA berperan mengkoordinir semua pelaksanaan kebijakan, program dan kegiatan pada instansi OPD (dinas-dinas, kantor-kantor, badan-badan, UPTD) yang berada dalam domain kewenangan dan tanggungjawabnya agar tetap berjalan lancar dan sesuai dengan tujuan dan target sasaran yang telah ditetapkan guna perwujudan visi dan misi organisasi birokrasi publiknya. SEKDA berperan mengkomunikasikan secara terbuka dan kontinyu segala kebijakan, program dan kegiatan instansional agar tidak timbul konflik kepentingan dan egosektoral, serta memastikan pelayanan public berjalan sesuai kebutuhan dan yang diharapkan oleh masyarakat di daerahnya. SEKDA berperan menfasilitasi dan memediasi segala urusan dan kepentingan pelayanan masyarakat agar pelayanan tetap berlangsung merata dan adil. SEKDA berperan sebagai pemberi motivasi dan dinamisator bagi segenap ASN untuk berkinerja optimal dan berprestasi kerja yang baik. Selain itu juga berperan sebagai pemberi energi dan pembangkit semangat kepada para birokrat dan aparatur dalam menghadapi setiap kesulitan dan tantangan tugas pekerjaan baik administrasi maupun pelayanan publik. Keenam, Supervisor, educator, trainer, learner, advocator, promotor dan empower organisasi birokrasi, ASN dan pelayanan publik (UU ASN, UU Perangkat Daerah), yaitu: SEKDA berperan sebagai pembina, pendidik, pelatih keterampilan, pembelajar, penasihat dan pemberdaya bagi organisasi birokrasinya (Setda, dinas-dinas, kantor-kantor, badan-badan, UPTD), bagi segenap SDM aparaturnya serta bagi masyarakat di daerahnya. SEKDA memiliki kewajiban dan tanggungjawab untuk melakukan pembinaan administrasi, pembinaan perilaku dan mental aparatur, memberi akses dan fasilitas pendidikan dan pelatihan untuk meningkatkan mutu pendidikan dan keterampilan kerja bagi aparatur, memberi arahan dan nasihat yang baik dan bijak, menjadi sumber pembelajar bagi aparatur, mempromosikan pegawai atau aparatur yang berkinerja/ berprestasi kerja untuk menduduki jabatan yang sesuai dengan kompetensinya, memberdayakan organisasi dan birokrasi pelayanan publik. Ketujuh, Implementor dan eksekutor kebijakan organisasi birokrasi, ASN dan pelayanan publik (UU ASN, UU Perangkat Daerah), yaitu: SEKDA berperan sebagai pengambil keputusan dan pelaksana kebijakan dan program-program pemerintah daerah pada organisasi birokrasinya (Setda, dinas-dinas, kantor-kantor, badanbadan, UPTD). Kedelapan, Controller, monitor dan evaluator organisasi birokrasi, ASN dan pelayanan publik (UU ASN, UU Perangkat Daerah), yaitu: SEKDA berperan sebagai pengawas, pengendali, pemantau dan penilai bagi setiap dan seluruh proses, aktivitas dan hasil (output-outcome) pelaksanaan kebijakan dan program-program pemerintah daerah pada organisasi birokrasinya (Setda, dinas-dinas, kantor-kantor, badan-badan, UPTD). 
Berdasarkan uraian analisis tersebut, diperoleh gambaran bahwa secara umum dan keseluruhan ada 8 (delapan) dimensi pokok dan utama kelompok peran strategis Sekretaris Daerah yaitu: (1) Pemimpin (Leader) dan/ atau pimpinan organisasi birokrasi dan ASN; (2) Manajer (Manager) organisasi birokrasi dan ASN; (3) Konseptor, konsultan, desainer, formulator kebijakan daerah, organisasi birokrasi dan ASN; (4) Administrator birokrasi, ASN dan pelayanan public; (5) Koordinator, komunikator, fasilitator, mediator, motivator, dinamisator, energisator organisasi birokrasi, ASN dan pelayanan public; (6) Supervisor, educator, trainer, learner, advocator, promotor dan empower organisasi birokrasi, ASN dan pelayanan publik (7) Implementor dan eksekutor kebijakan organisasi birokrasi, ASN dan pelayanan public; (8) Controller, monitor dan evaluator organisasi birokrasi, ASN dan pelayanan publik. Kedelapan peran strategis Sekretaris Daerah tersebut merupakan satu kesatuan yang tak terpisahkan dan saling integral satu sama lain.

\section{B. Tantangan Permasalahan Peran Sekretaris Daerah dalam Reformasi Birokrasi}

Sehubungan dengan upaya untuk mengakselerasi atau mempercepat pencapaian hasil area perubahan refomasi birokrasi khususnya di lingkup Pemerintah Daerah, dibentuk Tim Pengarah Reformasi Birokrasi (TPRB) Instansi Pemerintah Daerah yang dipimpin langsung oleh Kepala Daerah, sedangkan Sekretaris Daerah (SEKDA) berkedudukan sebagai Tim pelaksana sekaligus Sekretaris Tim TPRB dengan tugas adalah: (1) Memberikan arahan dalam penyusunan Road Map reformasi birokrasi serta menetapkan Road Map; (2) Memastikan pelaksanaan reformasi birokrasi sesuai dengan sasaran reformasi birokrasi nasional, yang dapat memberikan dampak pada perbaikan birokrasi dan memberikan dampak pada masyarakat; (3) Memonitor dan mengevaluasi pelaksanaan reformasi birokrasi secara berkala, termasuk pelaksanaan Quick Wins, dan memberikan arahan agar pelaksanaan reformasi birokrasi tetap berjalan konsisten, terarah sesuai dengan Road Map, dan berkelanjutan (Permen PAN \& RB No. 11 Tahun 2015 Tentang Road Map Reformasi Birokrasi 2015-2019). Dengan demikian, Sekretaris Daerah (SEKDA) berperan urgen, penting dan strategis sebagai Tim Pelaksana dan Sekretaris Tim TPRB di lingkungan organisasi birokrasi publik dan daerahnya.

Temuan hasil penelitian di Provinsi Sulawesi Selatan khususnya di Luwu Raya (eks wilayah pemerintahan Kerajaan Luwu) yang meliputi empat satuan organisasi pemerintahan daerah yakni Pemerintah Kota Palopo, Pemerintah Kabupaten Luwu, Pemerintah Kabupaten Luwu Timur, dan Pemerintah Kabupaten Luwu Utara menunjukkan bahwa Sekretaris Daerah (SEKDA) pada keempat daerah otonom tersebut belum optimal/ efektif melaksanakan perannya dalam akselerasi reformasi birokrasi di lingkungan organisasi birokrasinya. SEKDA belum memainkan peran-peran strategisnya dalam mewujudkan tujuan reformasi birokrasi yakni menciptakan birokrasi pemerintah yang profesional dengan karakteristik, berintegrasi, berkinerja tinggi, bebas dan bersih KKN, mampu melayani publik, netral, sejahtera, berdedikasi, dan memegang teguh nilai-nilai dasar dan kode etik aparatur negara. Demikian pula tiga sasaran pokok reformasi birokrasi yakni birokrasi yang bersih dan akuntabel, birokrasi yang efektif dan efisien, serta brokrasi yang memiliki pelayanan publik berkualitas, semuanya belum tercapai/ terwujud sebaagaimana mestinya. Pencapaian sasaran reformasi birokrasi dan tata kelola secara umum masih kurang dan belum menggembirakan. Hal tersebut ditunjukkan dengan tidak akan tercapainya beberapa target yang ditetapkan seperti persentase Pemda dengan opini Wajar Tanpa Pengecualian (WTP) atas laporan keuangan pemda (daerah), peringkat kemudahan berusaha, dan indeks efektifitas pemerintahan. SEKDA pada keempat satuan pemerintahan daerah di Luwu Raya tersebut belum mampu 
memainkan peranannya secara baik dan maksimal baik dalam hal kepemimpinan, manajer, administrator, koordinator, komunikator, fasilitator, mediator, motivator, dinamisator, energisator, supervisor, educator, trainer, learner, advocator, promotor dan empower, implementor dan eksekutor, maupun dalam hal controller, monitor dan evaluator organisasi birokrasi, ASN dan pelayanan public sehingga tujuan dan sasaran reformasi birokrasi masih sulit dicapai atau diwujudkan di lingkup organisasi birokrasi di daerahnya.

Temuan hasil penelitian tersebut sejalan dengan hasil evaluasi kebijakan reformasi birokrasi dari Kementerian PPN/ Bappenas Tahun 2010-2014 dan Kemen PAN-RB Tahun 2015-2019 mengenai sejumlah pokok permasalaham dan tantangan dalam pelaksanaan reformasi birokrasi terutama tiga sasaran reformasi birokrasi yaitu: Pertama, masalah birokrasi pada keempat satuan pemerintahan daerah di Luwu Raya masih memerlukan peningkatan akuntabilitas, masih memerlukan peningkatan komitmen Bupati/ Walikota serta Sekda dalam upaya pencegahan dan pemberantasan korupsi (KKN) di internal organisasi birokrasinya agar penyelenggaraan pemerintahan daerah mencerminkan penyelenggaraan yang bersih dan bebas KKN, manajemen kinerja masih perlu diperjelas penerapannya, manajemen pembangunan daerah masih perlu dioptimalkan. Kedua, Birokrasi pemerintah daerah pada keempat satuan pemerintahan daerah di Luwu Raya masih sangat memerlukan tata kelola pemerintahan daerah yang baik, peningkatan penegakan hukum, pengadaan barang dan jasa masih perlu disesuaikan dengan kebutuhan agar efektif dan efisien. Selain itu, kelembagaan birokrasi pemerintah daerah belum efektif, masih ada OPD/ SKPD yang dibentuk memerlukan evaluasi fungsi dan kinerjanya, tugas dan fungsi serta kewenangan SKPD masih perlu diperjelas agar tidak terjadi konflik egosektoral dalam perebutan proyek tertentu. Demikian pula penerapan e-government belum merata pada semua instansi/ SKPD, masih sering terjadi tumpang tindih sistem aplikasi, system informasi belum efisien dan belum terintegrasi secara menyeluruh. Terkait dengan manajemen SDM aparatur, juga belum berjalan efektif sebab masih banyak pemangku jabatan yang memerlukan penyesuaian kompetensi jabatan yang dimiliki agar kinerja/produktivitasnya dapat optimal. Demikian pula peningkatan integritas ASN/ PNS masih sangat diperlukan, manajemen kinerja pegawai dan system kompensasi masih perlu dimaksimalkan, sistem pembinaan karier pegawai masih perlu dievaluasi dan ditingkatkan. Terkait penggunaan anggaran, masih memerlukan adanya standarisasi sarana dan prasarana aparatur yang komprehensif, masih perlu membangun sistem dan budaya yang mendorong efisiensi, demikian pula besarnya biaya operasional masih perlu disesuaikan dengan kualitas pelayanan dan dampak pembangunan yang dihasilkan. Terkait masalah pendidikan dan pelatihan kepemimpinan bagi pegawai ASN juga masih perlu ditingkatkan dan disesuaikan untuk mendorong kinerja birokrasi daerah. Ketiga, Pelayanan public atau masyarakat pada keempat satuan pemerintahan daerah di Luwu Raya masih sangat memerlukan peningkatan kualitas, terutama dalam pelayanan perijinan yang masih belum berjalan efektif dan efisien, masih perlu peningkatan pengawasan untuk mencegah praktek pungutan liar (pungli) dalam pelayanan perijinan karena dapat menghambat iklim usaha dan investasi di daerah tersebut. Demikian pula praktek manajemen pelayanan publik masih perlu dimaksimalkan.

Temuan hasil penelitian menunjukkan bahwa Sekretaris Daerah diperhadapkan pada berbagai beban peran yang rumit/ kompleks sehingga seringkali harus mengalami konflik peran dalam melaksanakan tugas, kewajiban, fungsi, kewenangan dan perannya terutama dalam hal beban tugas dan tanggungjawab percepatan reformasi birokrasi di satuan unit pemerintahan daerahnya, sehingga tidak semua peran mampu dilaksanakan. Hal ini sesuai 
yang dikemukakan oleh Bruce J. Cohen (1992) mengenai peranan nyata (An acted Role), dalam hal ini Sekda hanya menjalankan peran yang benar-benar dianggap penting dan prioritas, sehingga seringkali mengesampingkan peranan yang dianjurkan (Prescribed Role) yang diharapkan masyarakat. Sekda seringkali mengalami konflik peranan (Role Conflict) sebab harus menghadapi sejumlah peran secara bersamaan terkait kedudukan, status, tugas, kewajiban, fungsi, kewenangan dan tanggungjawabnya. Sekda seringkali harus menjalankan perannya secara simultan sebagai pemimpin birokrasi, manajer, konseptor, konsultan, desainer, formulator kebijakan daerah, administrator birokrasi dan administasi pelayanan public, koordinator, komunikator, fasilitator, mediator, motivator, dinamisator, energisator organisasi birokrasi - ASN dan pelayanan public, supervisor, educator, trainer, learner, advocator, promotor dan empower organisasi birokrasi - ASN dan pelayanan public, implementor dan eksekutor kebijakan organisasi birokrasi-ASN dan pelayanan public, serta controller dan evaluator organisasi birokrasi - ASN dan pelayanan publik. Akibat banyaknya peran yang diemban oleh seorang Sekda tersebut maka semakin berkembang fenomena terjadinya pertentangan peran satu sama lain, kesenjangan peranan (role distance), kegagalan peran (role failure), ketegangan peranan (role strain). Dengan demikian, menjadi seorang Sekda bukanlah perkara mudah karena harus memikul banyak beban peran yang multikompleks dan multidimensional, sehingga revitalisasi peran menjadi penting.

\section{Model Revitalisasi Peran Srategis Sekretaris Daerah Dalam Mengakselerasi Reformasi Birokrasi}

Berdasarkan hasil penelitian, dapat dikemukakan analisis model revitalisasi peran strategis Sekretaris Daerah (Sekda) dalam mengakselerasi reformasi birokrasi pada pemerintahan daerah sebagai berikut.

\section{Revitalisasi peran Sekda sebagai Aktor Reinventer Government}

Sekretaris Daerah (Sekda) pada dasarnya merupakan aktor birokrat yang diberi beberapa status dan kewenangan penting dalam birokrasi publik oleh Negara melalui kebijakan hukum atau peraturan perundang-undangan yang berlaku dengan sebutan seperti perangkat daerah (Pasal 209), pembantu kepala daerah, top koordinator dan pelayan administratif birokrasi (Pasal 213 UU No.23 Tahun 2014 jo UU No.9 Tahun 2015 Tentang Pemerintahan Daerah), pejabat administrasi (top administrator), pejabat fungsional (top fungsionlis birokrasi), pejabat yang berwenang, pejabat pembina kepegawaian (top supervisor), top educator dan trainer (Pasal 1 UU ASN No.5 Tahun 2014, Pasal 1 PP No.11 Tahun 2017 Tentang Manajemen ASN). Semua gelar status dan kewenangan tersebut pada esensinya semakin mendukung dan memantapkan peran Sekda sebagai aktor reinventer government. Oleh karena itu, peran strategis Sekda seharusnya atau sangat penting untuk direvitalisasi ke dalam satu simpul peran yakni peran sebagai reinventer government dalam mengakselerasi reformasi birokrasi di lingkup otoritas pemerintahan daerahnya.

Peran sebagai reinventer government menuntut setiap Sekda untuk menjadi pioneer, pelopor serta berdiri di garis garda terdepan dalam mengelola birokrasi public berdasarkan prinsipprinsip reinventing government. Cara baru (new approach/ method) pengelolaan sector birokrasi publik ini telah digagas oleh David Osborne \& Ted Gaebler (1992), dan sangat relevan dengan perkembangan manajemen birokrasi pemerintahan daerah dewasa ini di Indonesia. Secara umum, bila diinternalisasikan dan diaktualisasikan ke dalam peran strategis Sekda dalam akselerasi reformasi birokrasi di lingkup pemerintahan daerah, terdapat beberapa poin penting dalam konstruksi pemikiran tersebut, yaitu: Pertama, Sekda 
mengkonstruksikan kepercayaan yang tinggi dan mendalam mengenai makna dan arti penting sebuah pemerintahan khususnya pemerintahan daerah sebagai suatu mekanisme dalam proses pengambilan keputusan atau pembuatan kebijakan (policy making) mengenai suatu program dan kegiatan dalam penyelenggaraan urusan pemerintahan, pembangunan dan pelayanan public maupun dalam menyelesaikan masalah-masalah klasik dan kontemporer pada wilayah pemerintahan yang menjadi otoritas Sekda. Kedua, Sekda mengkonstruksikan kepercayaan mendalam mengenai kebutuhan mendesak birokrasi pemerintahan yang efektif guna menciptakan, membangun dan memelihara eksistensi dan fungsi-fungsi komunitas masyarakat yang beradab (civil society). Dalam konteks ini, Sekda dituntut mengambil peran aktif melakukan perubahan dengan menciptakan birokrasi pemerintahan daerah yang efisien dan efektif sebagaimana yang menjadi harapan public atau masyarakat di wilayahnya. Menurut Osborne dan Gaebler bahwa pemerintahan era industrial dengan birokrasi dan standarisasinya yang terpusat dan besar serta dengan mekanismemekanisme pelayanan yang satu-untuk-melayani-semua, tak akan mampu menghadapi tantangan-tantangan yang muncul dalam sebuah masyarakat informasi dan ekonomi berbasis pengetahuan yang berubah-ubah dengan begitu cepat. Hal ini mengisyaratkan bahwa Sekda perlu memainkan peran sebagai reinventer government secara luas dalam menetapkan kebijakan dan program strategis melalui reformasi birokrasi untuk menghadapi aneka tantangan internal dan eksternal dari dinamika lalu lintas kepentingan dan kebutuhan masyarakat atas kualitas pelayanan birokrasi yang semakin meningkat dan ekstensif. Ketiga, Sekda memiliki keyakinan akan dimungkinkannya perbaikan birokrat dan aparatur di birokrasinya. Dalam hal ini, peran Sekda sebagai reinventer government dalam reformasi birokrasi adalah melakukan pengkajian dan analisa secara menyeluruh terhadap sistem kerja organisasi birokrasinya, mengevaluasi kelemahan-kekurangan yang ada, mengambil langkahlangkah keputusan dan tindakan perbaikan yang diperlukan, serta menata sistem birokrasinya secara keseluruhan. Keempat, Sekda berkeyakinan mampu menciptakan lingkungan birokrasi yang sehat dan lebih baik. Dalam kontes ini, peran Sekda sebagai reinventer government dalam reformasi birokrasi adalah mengatasi masalah-masalah internal birokrasi baik masalah SDM, infrastruktur, sarana prasarana, fasilitas, teknologi terlebih masalah keterbatasan kemampuan keuangan/ anggaran (finansial) dalam melaksanakan suatu kebijakan dan program peningkatan kualitas layanan public. Untuk tujuan ini, Sekda harus memiliki political will dan kemampuan komunikasi serta lobi-lobi untuk mengajak pemilik modal/ investor/ pelaku usaha menjalin kerjasama kemitraan strategis dalam kegiatan investasi pada sector-sektor pelayanan public di daerahnya. Terkait hal ini, tentunya Sekda harus berkoordinasi dengan Kepala Daerah, kepala instansi terkait, DPRD serta tokoh masyarakat setempat. Kelima, Sekda meyakini pentingnya kesetaraan dan kesempatan yang sama bagi semua warga masyarakat (individu dan kelompok) dalam melaksanakan suatu program dan kegiatan maupun dalam mengelola dampak persaingan yang timbul. Dalam kontes ini, peran Sekda sebagai reinventer government dalam reformasi birokrasi adalah menciptakan inovasi-inovasi baru dalam memenuhi kebutuhan daerah dan masyarakatnya, memiliki variasi dan pilihan-pilihan alternative kebijakan dalam mendekati setiap masalah dan solusi pemecahannya berdasarkan nilai-nilai kearifan budaya lokal, menerapkan sistem zonasi potensi sumber daya (baik sumber daya alam dan lingkungan maupun sumber daya manusia) yang ada beserta pemanfaatan dan pengelolaannya, menciptakan suatu strategi pelayanan publik yang adil dan merata, menerapkan prinsip kesetaraan dan akses kesempatan yang sama terhadap fasilitas pelayanan publik, meminimalisir resiko dan ketimpangan, mencegah timbulnya konflik diantara pihak-pihak berkepentingan dalam masyarakat 


\section{Revitalisasi peran Sekda sebagai Leader Manager Reformasi Birokrasi}

Eksistensi Sekretaris Daerah (Sekda) memiliki status dan kewenangan penting sebagai pemimpin (top leader) organisasi sekretariat daerah, memimpin satuan organisasi perangkat daerah/ OPD, sebagai decision-policy maker birokrasi (Pasal 213 UU No.23 Tahun 2014 jo UU No.9 Tahun 2015), sebagai top manager PNS/ ASN, pejabat pimpinan tinggi birokrasi, pejabat yang berwenang, pejabat pembina kepegawaian (top supervisor) (Pasal 1 UU ASN No.5 Tahun 2014, Pasal 1 PP No.11 Tahun 2017 Tentang Manajemen ASN). Status dan kewenangan tersebut sangat mendukung peran Sekda sebagai aktor leader-manager. Oleh karena itu, peran strategis Sekda seharusnya atau sangat penting untuk direvitalisasi ke dalam satu simpul peran yakni peran sebagai leader-manager dalam mengakselerasi reformasi birokrasi di lingkup otoritas pemerintahan daerahnya.

Peran sebagai leader-manager tersebut menuntut setiap Sekda untuk memainkan peran ganda sebagai pemimpin dan sekaligus manajer reformasi birokrasi. Sebagai leader, Sekda harus mampu memimpin perubahan secara bertahap, demokratis dan progresif dalam menjalankan fungsi-fungsi leadership atau kepemimpinannya yakni memberikan instruksi atau perintah, memberi motivasi, melakukan pengawasan serta menggunakan pengaruh kekuasaannya kepada seluruh kepala instansi (dinas, kantor, badan, UPTD) dan semua aparatur (ASN)/ PNS yang ada di lingkup otoritas pemerintahan daerahnya untuk secara bersama-sama bergerak maju melaksanakan program-program dan kegiatan-kegiatan reformasi birokrasi di internal organisasinya. Mengacu kepada konsep leader manager Donald W. Wilson dalam bukunya The Next 25 Years Indonesia's Journey into The Future serta rekomendasi hasil penelitiannya yang mendalam mengenai pemerintahan yang baik (good government) di Indonesia, maka seorang Sekda sebagai manajer pemimpin reformasi birokrasi harus memiliki karakteristik yang khas antara lain: Pertama, Visioner, yaitu Sekda mampu berpikir dalam kerangka jangka panjang dan demi masa depan, tidak terpaku pada hambatan-hambatan jangka pendek seperti krisis sehari-hari, laporan kuartal atau review kinerja tahunan; Kedua, Sekda berpikir dan berjiwa besar, mampu mengarahkan perhatiannya lebih jauh dan luas pada kepentingan yang lebih besar daripada sekedar hanya berkutat pada domain tanggung jawabnya semata, mampu memahami berbagai hal baik relasi-relasi internal antar unit kerja maupun keterkaitan seluruh SKPD/ OPD (kantor, dinas, badan), demikian pula pengaruh-pengaruh, kebutuhan-kebutuhan serta kondisi-kondisi eksternal daerah dan masyarakatnya dalam berbagai aspek (sosial, budaya, pendidikan, kesehatan, ketenagakerjaan, permukiman dan perumahan, ekonomi, industri dan perdagangan, perhubungan dan transportasi, lingkungan, pertanian, perkebunan, peternakan, pertambangan dan energi, keolahragaan, kepariwisataan, hukum, politik, pertahanan keamanan); Ketiga, Sekda mampu menggunakan pengaruh kepemimpinan dan kekuasaannya untuk menghimpun/ mempersatukan semua unsur/ elemen kelompok masyarakat yang berbeda-beda latar belakang sosial budaya ekonomi dan kepentingankebutuhannya; mampu mengelola potensi social capital masyarakatnya yang pluralis, heterogen dan multicultural menjadi sumber daya pembangunan daerah; mampu menggerakkan masyarakatnya untuk berperan dan berpartisipasi dalam berbagai program dan kegiatan pembangunan daerah (kota dan desa) serta pelayanan public; Keempat, Sekda memiliki pengetahuan dan pemahaman mengenai arti penting kepemimpinan dan manajemen dalam mengelola potensi psikososial masyarakatnya maupun dalam mengelola konflik dan resolusinya, berpikir rasional dan realistis dalam menghadapi setiap situasi dan kondisi serta masalah yang timbul, mampu menjabarkan nilai-nilai dan visi organisasinya ke 
dalam perilaku dan tindakan-tindakannya, mampu menjadi motivator dan membangkitkan kepercayaan masyarakat terhadap pemimpin dann pejabat birokrasi pemerintahan, mampu menunjukkan ketauladanan dan integritas yang baik dan positif; Kelima, Sekda memiliki kemampuan beradaptasi atau menyesuaikan diri dengan beragam situasi dan tuntutan aparatur (ASN/PNS) dan masyarakatnya, memiliki komptensi sosial dan stratejik yang baik dalam menjalin hubungan komunikasi baik di lingkungan birokrasi maupun lingkungan sosial masyarakat, mampu mengelola setiap perubahan menjadi sesuatu yang bermanfaat serta positif dan konstruktif, mampu menjaga nilai-nilai dan integritas moralnya, serta memiliki kemampuan membangkitkan kesadaran aparatur (ASN/PNS) dan masyarakatnya atas hak-hak serta kewajiban dan tanggungjawabnya; Keenam, Sekda memiliki kemampuan membaca tanda-tanda perubahan internal lingkungan organisasi (Sekretariat Daerah, dinas, kantor, badan) maupun lingkungan eksternal masyarakat di daerahnya untuk melakukan penyesuaian-penyesuaian kebutuhan pengelolaan organisasi dan aparatur (ASN/PNS) serta pelayanan kebutuhan masyarakatnya; Ketujuh, Sekda memiliki kemampuan mengelola dan memanfaatkan potensi sumber daya (organisasi dan aparatur (ASN/PNS) dan bakat yang terbaik yang ada di lingkungan birokrasi dan masyarakatnya untuk mendukung pertumbuhan, perkembangan dan kemajuan organisasi birokrasi, daerah dan masyarakatnya. Selain itu, memiliki kepercayaan diri yang tinggi atas kompetensi yang dimiliki dan sikap rendah hati yang baik sehingga tidak merasa terancam dan tersaingi oleh pihak-pihak lain di dalam organisasinya.

\section{Revitalisasi peran Sekda sebagai Entrepreuner Birokrasi}

Sekretaris Daerah (Sekda) menyandang status dan kewenangan penting sebagai pembantu kepala daerah, top leader organisasi sekretariat daerah, memimpin satuan organisasi perangkat daerah/ OPD, top koordinator dan pelayan administratif birokrasi (Pasal 213 UU No.23 Tahun 2014 jo UU No.9 Tahun 2015), top manager PNS/ ASN, pejabat administrasi (top administrator), pejabat fungsional (top fungsionlis birokrasi), pejabat yang berwenang, pejabat pembina kepegawaian (top supervisor), top educator dan trainer (Pasal 1 UU ASN No.5 Tahun 2014, Pasal 1 PP No.11 Tahun 2017). Semua status dan kewenangan tersebut cukup mendukung peran Sekda sebagai aktor Entrepreuner birokrasi. Oleh karena itu, peran strategis Sekda seharusnya atau sangat penting untuk direvitalisasi ke dalam satu simpul peran yakni peran sebagai Entrepreuner dalam mengakselerasi reformasi birokrasi di lingkup otoritas pemerintahan daerahnya.

Peran sebagai Entrepreuner tersebut menuntut setiap Sekda untuk memiliki jiwa dan semangat entrepreneurship atau kewirausahaan/ kewiraswastaan serta memainkan peran sebagai pemimpin, manajer atau pengelola birokrasi yang berjiwa wiraswasta atau wirausawan, namun bukan sebagai businessman. Untuk menjalankan perannya sebagai Entrepreuner tersebut, seorang Sekda dituntut kemampuan mengelola potensi kekuatan sumber daya yang dimiliki (baik sumber daya organisasi dan SDM aparatur, sarana prasarana, teknologi, finansial) untuk meraih peluang bagi terwujudnya birokrasi yang ideal dan keluar dari patologi birokrasi, mampu mengatasi kelemahan dan meminimalisir ancaman, mampu mengelola tantangan menjadi hasil karya yang positif, mampu menggunakan kesempatan yang ada untuk mengembangkan kreativitas dan inovasi-inovasi baru dalam mengelola dan mewujudkan reformasi birokrasi, berani mengambil keputusan dan resikonya, senantiasa konsisten menjalankan tugas-fungsi-kewenangan dan tanggungjawabnya, memiliki komitmen dan semangat kemandirian yang tinggi, mampu menunjukkan produktivitas kerja yang tinggi, mampu menjadi motivator atau pemberi semangat bagi organisasi dan aparatur 
(ASN/PNS) serta masyarakatnya, mampu menciptakan iklim organisasi dan lingkungan kerja yang baik, mampu menciptakan organisasi yang ramping dan kaya fungsi serta efisien dan efektif, mampu menerapkan manajemen pemerintahan dalam tata kelola organisasi dan ASN yang baik, mampu memanfaatkan IPTEK (e-government) untuk pelayanan public dan kemajuan organisasinya, mampu menciptakan dan mengembangkan sikap yang responsive terhadap setiap kebutuhan dan masalah yang dihadapi oleh organisasi dan aparatur (ASN/PNS) serta masyarakatnya, mampu menjadikan organisasinya sebagai learning organization bagi aparatur (ASN/PNS) serta masyarakatnya. Singkatnya, Sekda mampu mengoptimalkan potensi sumber daya aparaturnya untuk berkinerja dan berprestasi kerja yang baik serta berkontribusi bagi organisasinya, mampu membangun dan mengembangkan organisasi birokrasi publik masa depan yang siap menghadapi berbagai tugas dan tantangantantangan baru dalam dinamika perubahan lingkungan internal dan eksternal yang berlandaskan jiwa dan semangat entrepreneurship sehingga organisasi yang dipimpin (Sekretariat Daerah, dinas-dinas, kantor-kantor, badan-badan dan UPTD) menjadi responsive, produktif, inovatif, efisien dan efektif, akuntabel, profesional serta unggul dalam persaingan baik di tingkat local, nasional maupun global.

\section{4, Revitalisasi peran Sekda sebagai Aktor New Public Management (NPM)}

Kedudukan dan status Sekda sebagai pemimpin dan manajer birokrasi publik, selain dituntut menjadi entrepreuner juga perlu memiliki political will dan motivasi untuk belajar pada sektor swasta (private sector) dalam hal menjadi manajer professional, kompetensi yang baik dalam mengelola sumber daya organisasi (SDM aparatur, sarana prasarana, fasilitas, teknologi, waktu, dan finansial) yang dimiliki secara efisien, produktif dan efektif serta inovatif untuk mencapai visi-misi serta tujuan dan sasaran organisasi sesuai prinsip-prinsip manajemen (perencanaan, pengorganisasian, pengelolaan, pengawasan, evaluasi). Inilah makna dari peran Sekda sebagai aktor New Public Management (NPM). Seorang Sekda perlu mempunyai rasa memiliki yang tinggi dan tanggungjawab yang besar terhadap kemaslahatan organisasi dan kesejahteraan aparaturnya serta masyarakat yang dilayaninya, dan bukan sekedar sebagai pejabat yang terjebak pada tugas-tugas regulative normative belaka dalam memenuhi kewajibannya membantu kepala daerah. Dengan rasa memiliki dan tanggungjawab tersebut maka Sekda akan senantiasa belajar menerapkan prinsip-prinsip kehati-hatian/ kecermatan, produktivitas, inovasi, efisiensi, efektivitas, akuntabilitas, soliditas-solidaritas, persaingan sehat, profesionalisme serta manajemen resiko dan manajemen administrasi dalam mengelola organisasi birokrasinya.

Konsepsi mengenai peran Sekda sebagai aktor NPM tersebut sesuai yang dikemukakan oleh Garson dan Overman bahwa: "An interdisciplinary study of the generic aspects of administration ... a blend of the plannning, organizing, and controlling functions of management with the management of human, financial, physical, information and political resources." Artinya, studi interdisipliner mengenai aspek-aspek generik pemerintahan merupakan campuran antara fungsi perencanaan, pengorganisasian, pengawasan dari manajemen dengan manajemen sumber daya manusia, sumber daya keuangan, sumber daya fisik, sumber daya informasi dan sumber daya politik. Pendapat ini mengisyaratkan bahwa dalam reformasi birokrasi, Sekda dituntut untuk mampu memainkan peran lebih luas dalam menerapkan prinsip-prinsip manajemen professional ke dalam manajemen organisasi (Sekretariat Daerah, dinas-dinas, kantor, badan, UPTD), manajemen SDM aparatur (ASN/PNS), manajemen keuangan organisasi birokrasi, manajemen fasilitas dan teknologi, manajemen basis pangkala data dan sistem informasi organisasi serta daerah dan pelayanan 
masyarakat, manajemen komunikasi politik dengan Kepala Daerah dan DPRD serta elit-elit politik lainnya.

Penerapan NPM tersebut mengisyaratkan pula bahwa Sekda berperan penting sebagai manajer birokrasi yang professional dalam menjabarkan janji-janji politik Kepala Daerah terhadap masyarakat ke dalam agenda-agenda formulasi kebijakan, desain program dan kegiatan serta implementasinya secara terencana dan terorganisir dengan baik. Dengan cara demikian maka kepercayaan masyarakat terhadap Kepala Daerah dan organisasi birokrasi pemerintah daerah dapat semakin meningkat. Demikian pula kepercayaan Kepala Daerah terhadap Sekretaris Daerah akan semakin meningkat sehingga hubungan koordinasi dan kerjasama diantara keduanya semakin lebih baik. Selain itu, juga akan terbangun hubungan koordinasi dan kerjasama segitiga yang baik antara Sekda, Kepala Daerah dan DPRD, bahkan hubungan komunikasi dengan masyarakat akan semakin lebih baik pula karena dilandasi oleh sikap saling kepercayaan satu sama lain. Dengan demikian, aktualisasi peran Sekda sebagai aktor NPM (manajer professional) akan sangat mendukung kelancaran reformasi birokrasi sebab visi misi dan janji-janji politik Kepala Daerah kepada masyarakat dapat terealisasi dengan baik secara bertahap dan nyata: pelayanan public semakin lebih baik, pembangunan semakin meningkat, dan penyelenggaraan urusan pemerintahan daerah juga semakin lancar.

Aktualisasi peran Sekda sebagai aktor NPM dalam reformasi birokrasi tersebut sesuai pendapat Vigoda bahwa "An Approach in public administration that employs knowledge and experiences acquired in business management and other disciplines to improve efficiency, effectiveness, and general performance of public services in modern bureaucracies." Artinya, NPM sebagai sebuah pendekatan dalam administrasi public yang memanfaatkan pengetahuan dan pengalaman-pengalaman yang didapat di manajemen bisnis dan displindisiplin ilmu lain untuk meningkatkan efisiensi, efektivitas dan kinerja umum dan layananlayanan publik birokrasi-birokrasi modern. Hal ini mengisyaratkan bahwa Sekda harus mau belajar ilmu pengetahuan dan pengalaman-pengalaman manajer pada organisasi-organisasi swasta yang berorientasi profit (profit-oriented organization) untuk mengembangkan gagasan pemikiran dan inovasi-inovasi baru ataupun mengadopsi nilai-nilai, cara-cara pendekatan/ metode baru dalam mengelola organisasi birokrasi publiknya (non profit-oriented organization) berdasarkan konsep manajemen professional dan prinsip NPM. Dalam reformasi birokrasi, Sekda dituntut belajar seni dan strategi mengelola organisasi publiknya dari berbagai konsep, teori maupun pengalaman praktek perusahaan-perusahaan swasta berskala besar dalam mengelola usaha dan organisasi perusahaan sehingga dapat benar-benar terwujud pengelolaan birokrasi yang baik dan efiisien di Sekretariat Daerah, dinas-dinasi, kantor-kantor, badan-badan, UPTD.

Tuntutan aktualisasi peran Sekda sebagai aktor NPM dalam reformasi birokrasi tersebut sesuai yang dikemukakan oleh Azhar Kasin (2010;12-13) bahwa alasan mendesak atas adanya tuntutan reformasi terhadap birokrasi di Indonesia secara umum tidaklah berbeda dengan yang dialami/ dihadapi oleh negara-negara maju yakni karena dipicu dan dipacu oleh ketidakmampuan birokrasi pemerintahan menyelenggarakan pelayanan publik yang efisien, serta adanya keinginan masyarakat agar birokrasi lebih responsif terhadap kebutuhan masyarakat. Disamping itu, terdapat pengaruh perubahan paradigma dalam ilmu administrasi publik dari keharusan birokrasi pemerintahan terlibat mulai dari reformasi kebijakan public sampai penyelenggaraan pelayanan publik menjadi peranan birokrasi pemerintahan yang lebih banyak pada pelayanan publik menjadi peranan birokrasi pemerintahan yang lebih banyak pada tataran formulasi kebijakan dan pengaturan kehidupan 
masyarakat, pemberian peluang kepada sektor bisnis dan civil society dalam penyelenggaraan pelayanan.

Mengacu kepada sepuluh prinsip Reinventing Government Osborne dan Geabler tersebut, maka Sekda sebagai aktor NPM dalam reformasi birokrasi dituntut untuk berperan: Pertama, sebagai katalisator (Steering rather than rowing) yakni tidak melaksanakan sendiri pembangunan tapi cukup mengendalikan sumber-sumber yang ada di masyarakat. Kedua, sebagai pemberdaya masyarakat dalam pelayanan publiknya (Empower Communities to solve their own problems, rather than merely drliver services). Untuk tujuan ini, Sekda perlu melibatkan organisasi-organisasi sosial kemasyarakatan seperti Koperasi, LSM, dan sebagainya untuk memecahkan permasalahannya sendiri, terutama seperti masalah keamanan, kebersihan, kebutuhan sekolah, pemukiman murah dan lainnya. Ketiga, sebagai pencipta persaingan dalam setiap sector pelayanan public (Promotor and encourage competition, rather than monopolies) antara sektor usaha swasta dan pemerintah sehingga mendorong organisasi public untuk bekerja secara lebih profesional dan efisien. Keempat, sebagai missioner (Be driven by missions rather than rules) yang harus lebih menfokuskan aktivitasnya pada pencapaian "misi organisasi" pemerintah daerah daripada sekedar melaksanakan peraturan-peraturan. Kelima, berorientasi pada kinerja yang baik (Result oriented by funding outcomes rather than outputs). Keenam, lebih mengutamakan pemenuhan kebutuhan masyarakat daripada kebutuhan birokrat (Meet the needs of the customer rather those the bureaucracy). Ketujuh, lebih berkonsentrasi pada upaya penghasilan profit atau perolehan uang dari pada sekedar menghabiskan pengeluaran belanja yang banyak (Concentrate on earning money rather than just spending it) sehingga harus hemat dan efisien dalam menggunakan anggaran. Kedelapan, antisipator (Invest in preventing problems rather than curing) atau lebih mengedepankan aspek pencegahan daripada menanggulangi masalah yang timbul sehingga akan terbangun "mental switch" pada aparatur pemerintah. Kesembilan, lebih mengutamakan desentralisasi kekuasaan atau kewenangan dalam birokrasi pemerintahan serta partisipasi dalam pengembangan kerjasama tim daripada sekedar membangun hirarki (Decentralize authorty rather than build hierarchy) sehingga semua aparatur terutama di level bawah akan memiliki keleluasaan untuk berkreasi dan berani mengambil inisiatif yang diperlukan dalam melaksanakan dan menyelesaikan tugas pekerjaannya. Kesepuluh, membuat kebijakan serta menyelesaikan masalah dengan memperhatikan/ memperhitungkan kekuatan pasar (Solve problems by influencing market forces rather than by treaning public programs).

\section{Revitalisasi peran Sekda sebagai Aktor Strategi Banishing Bureucracy Reformasi Birokrasi}

Kedudukan dan status Sekda sebagai pemimpin dan manajer birokrasi publik, dituntut untuk berperan sebagai aktor perancang dan pengatur strategi reformasi birokrasi. Dalam konteks ini, David Osborne dan Peter Plastrik dalam bukunya berjudul "Banishing Bureucracy" mengemukakan paradigma strategi baru lainnya yakni mewirausahakan birokrasi melalui 5 strategi (5 core strategies 5(Cs) yaitu: Pertama, Strategi Inti (Center Strategy), dalam hal ini Sekda berperan menata kembali secara jelas mengenai tujuan, peran dan arah organisasi birokrasinya; Kedua, Strategi Konsekuensi (Consequency Strategy), dalam hal ini Sekda berperan menerapkan strategi untuk mendorong "persaingan sehat" guna meningkatkan motivasi dan kinerja ASN/ PNS melalui penerapan sistim kompensasi dan ganjaran "Reward and Punishment" dengan memperhitungkan resiko ekonomi dan pemberian penghargaan kepada ASN/ PNS yang berkinerja baik atau berprestasi kerja tinggi; Ketiga, Strategi 
Pelanggan (Customer Strategy), dalam hal ini Sekda mengedepankan tanggung jawabnya terhadap warga masyarakat yang dilayaninya. Oleh karena itu, organisasi birokrasi harus memberikan pelayanan yang berkualitas, unggul dan cepat kepada masyarakat serta memberikan kepastian hukum; Keempat, Strategi Kendali (Control Strategy), dalam hal ini Sekda berperan merubah lokasi dan bentuk kendali di dalam organisasi birokrasi terutama kepada lapisan organisasi paling bawah yakni pelaksana atau masyarakat. Kendali organisasi birokrasi dibentuk berdasarkan visi dan misi Pemerintah Daerah ataupun Sekretariat Daerah yang telah ditetapkan sehingga terjadi pemberdayaan organisasi birokasi, ASN/ PNS dan masyarakat; Kelima, Strategi Budaya (Cultural Strategy), dalam hal ini Sekda berperan merubah budaya kerja organisasi yang terdiri dari unsur-unsur kebiasaan, emosi dan psikologi sehingga pandangan masyarakat terhadap budaya organisasi publik inipun berubah (tidak lagi memandang rendah). Kelima strategi Banishing Bureucracy tersebut memiliki perbedaan dengan Reinventing Government. Yang pertama menyangkut pembahasan secara preskriptif mengenai penciptaan strategi untuk mentransformasikan sistem dari organisasi birokrat ke organisasi wirausaha dengan memberikan know how untuk aplikasinya, sedangkan yang kedua menyangkut reinvensi dengan karakteristik manajemen pemerintah yang bersifat wirausaha secara deskriptif.

\section{Revitalisasi peran Sekda sebagai Aktor Reformasi Birokrasi berbasis kearifan budaya lokal}

Kedudukan dan status Sekda sebagai pemimpin dan manajer birokrasi publik, dituntut untuk berperan sebagai aktor reformasi birokrasi berbasis kearifan budaya lokal. Sekda berada ditengah-tengah masyarakat dan daerah yang menjadi akar dan habitat tempat tumbuh serta berkembangnya nilai-nilai kearifan budaya local, sehingga sudah selayaknyalah jika nilai-nilai kearifan budaya local yang ada dan berlaku dalam kehidupan masyarakat diadopsi, diinternalisasikan dan diaktualisasikan ke dalam budaya kerja organisasi birokrasi public (Nurmandi, 2005).. Di Sulawesi Selatan khususnya di Luwu Raya (Kota Palopo, Kabupaten Luwu, Kabupaten Luwu Timur dan Luwu Utara) yang merupakan eks wilayah dan pusat pemerintahan Kerajaan Luwu dengan masa golden past selama 12 abad lamanya, memiliki kekayaan nilai-nilai luhur (yakni Adele/ keadilan, Lempuq/ kejujuran, Tongeng/ kebenaran) serta berbagai nilai-nilai kearifan budaya local lainnya seperti Sirina Passe', sipakatau, sipatuwo sipatokkong, si bali parri, dan lain sebagainya. Nilai-nilai kearifan budaya local tersebut sangat baik untuk direvitalisasi, diinternalisasikan dan diaktualisasikan ke dalam budaya organisasi birokrasi pemerintahan daerah di Luwu Raya tersebut, sehingga nilai-nilai kearifan budaya local akan bertemu dan menyatu dengan nilai-nilai budaya organisasi modern yang pada akhirnya akan melahirkan nilai-nilai budaya organisasi yang baru

\section{KESIMPULAN}

Secara umum dan keseluruhan, ada 8 (delapan) dimensi pokok dan utama kelompok peran strategis seorang Sekretaris Daerah dalam birokrasi pemerintahan yaitu: (1) Pemimpin (Leader) dan/ atau pimpinan organisasi birokrasi dan ASN; (2) Manajer (Manager) organisasi birokrasi dan ASN; (3) Konseptor, konsultan, desainer, formulator kebijakan daerah, organisasi birokrasi dan ASN; (4) Administrator birokrasi, ASN dan pelayanan public; (5) Koordinator, komunikator, fasilitator, mediator, motivator, dinamisator, energisator organisasi birokrasi, ASN dan pelayanan public; (6) Supervisor, educator, trainer, learner, advocator, promotor dan empower organisasi birokrasi, ASN dan pelayanan publik (7) 
Implementor dan eksekutor kebijakan organisasi birokrasi, ASN dan pelayanan public; (8) Controller, monitor dan evaluator organisasi birokrasi, ASN dan pelayanan publik. Kedelapan peran strategis Sekretaris Daerah tersebut merupakan satu kesatuan yang tak terpisahkan dan saling integral satu sama lain. Tantangan permasalahan terhadap peran strategsi Sekretaris Daerah adalah diferensiasi peranan nyata (an acted role), pengesampingan peranan yang dianjurkan (prescribed role) yang diharapkan masyarakat, konflik peran (role conflict) dan pertentangan peran satu sama lain, kesenjangan peranan (role distance), kegagalan peran (role failure), ketegangan peranan (role strain). Model revitalisasi peran strategis Sekretaris Daerah dalam akselerasi reformasi birokrasi adalah revitalisasi peran Sekda sebagai aktor Reinventer Government, Leader Manager birokrasi, Entrepreuner birokrasi, aktor New Public Management (NPM), aktor Strategi Banishing Bureucracy reformasi birokrasi, dan revitalisasi peran sebagai aktor reformasi birokrasi berbasis kearifan budaya lokal. Oleh karena itu disarankan untuk mempertimbangkan penerapan model revitalisasi peran strategis Sekretaris Daerah dalam akselerasi reformasi birokrasi tersbut.

\section{DAFTAR PUSTAKA}

Destianingrum, B., Hananto, U. D., \& Sa'adah, N. (2017). Profesionalisme Birokrat Dalam Implementasi Good Governance Menuju Terwujudnya Negara Bebas Korupsi Kolusi Nepotisme (KKN) DI KOTA SEMARANG. Diponegoro Law Journal, 6(2), 1-17.

Hamidi, J. (2011). Paradigma Baru Pembentukan Dan Analisis Peraturan Daerah (Studi Atas Perda Pelayanan Publik Dan Perda Keterbukaan Informasi Publik). Jurnal Hukum Ius Quia Iustum, 18(3), 336-362.

Hamirul, H., Masnun, A., \& Elsyra, N. (2018). Profesionalisme Aparatur Sipil Negara dalam rangka mengatasi Patologi Pelayanan Publik. Jurnal Marketing, 2(2), 133-148.

Hendrajit, H. (2017). Pergeseran Sentral Geopolitik Internasional, dari Heartland ke Asia Pasifik. Jurnal Kajian Lemhannas RI, 5(1), 31-41.

Kusmanto, H. (2014). Partisipasi Masyarakat dalam Demokasi Politik. JPPUMA: Jurnal Ilmu Pemerintahan dan Sosial Politik UMA (Journal of Governance and Political Social UMA), 2(1), 78-90.

Moleong, J, L. (2014). Metodologi Penelitian Kualitatif. Cetakan Kesebelas Bandung: Remaja Rosdakarya..

Miles B. M \& Huberman M A. (2012). Metodologi Penelitian Sosial. Ed.II. Jakarta: Penerbit Bumi Aksara.

Moonti, R. M., Ismail, N., Karepoan, J. K., \& Djanggih, H. (2018). Pelaksanaan Pengukuran Prestasi Kerja Terhadap Aparatur Sipil Negara (ASN) di Dinas Pertanian Provinsi Gorontalo. Jurnal Ilmiah Kebijakan Hukum, 12(2), 151-161.

Nurmandi, A. (2005). Perilaku Birokrasi Publik di Indonesia: Sebuah Kajian Teoritis. Sosiohumaniora, 7(2), 143.

Sitindjak, V. (2017). KONSEP REFORMASI BIROKRASI. Jurnal Inspirasi, 8(2), 79-89.

Soetjipto, A. W., Yuliestiana, A. T. D., Suryani, D. P. S., Kinanthi, D. K., Tamzil, C. F., Parameswari, P., \& Waworuntu, A. (2019). Transnasionalisme: peran aktor non negara dalam hubungan internasional. Yayasan Pustaka Obor Indonesia. 
181 | Kalabbirang Law Journal, 2 (1): 69-77

Sosiawan, E. A. (2015, June). Evaluasi implementasi e-government pada situs web pemerintah daerah di Indonesia: Prespektif content dan manajemen. In Seminar Nasional Informatika (SEMNASIF) (Vol. 1, No. 5).

Thoha, M. (2007). Birokrasi pemerintah Indonesia di era reformasi. Kencana.

Wasistiono, S. (2010). Menuju Desentralisasi Berkeseimbangan. Jurnal Ilmu Politik, 21, 1-25. 